\title{
A CASE OF URBAN MIMICRY: CITRA RAYA, THE SINGAPORE OF SURABAYA
}

\author{
Dyah Erti Idawati \\ Department of Architecture, Syiah Kuala University, Banda Aceh, Indonesia \\ e-mail: didawati@yahoo.com
}

\begin{abstract}
Under the forces of globalization, there is considerable pressure for cities to enhance their attractiveness in numerous ways in order to attract capital. Surabaya, Indonesia's second largest city, promotes a strategy to match the aesthetic criteria associated with imagined global metropolises. Singapore has been extremely influential in inspiring other cities in the South East Asian region and a dream to be another Singapore certainly appears in Surabaya. Imitating Singapore's gleaming towers and exotic waterfront, Surabaya has sought to eliminate backward scenes including more traditional settlement forms. Interestingly, this trend to create an image of Singapore is not only supported by the business community but by the Surabaya's government as well. This paper explores how the image of Singapore has influenced the shape of Surabaya in both systematic and practical ways, particularly addressing to what extent this obsession with Singapore has affected Surabaya images and identities?
\end{abstract}

Keywords: Surabaya, image, identity, Singapore, urban mimicry

\begin{abstract}
ABSTRAK
Di bawah kekuatan globalisasi, ada tekanan yang cukup untuk kota untuk meningkatkan daya tarik mereka dalam berbagai cara untuk menarik modal. Surabaya, kota terbesar kedua di Indonesia, mempromosikan strategi untuk mencocokkan kriteria estetika dengan dengan kota-kota global yang dibayangkan. Singapura telah sangat berpengaruh dalam menginspirasi kota-kota lain di kawasan Asia Tenggara dan mimpi untuk menjadi Singapore lain pasti muncul di Surabaya. Meniru berkilauan menara Singapura dan pantai eksotis, Surabaya telah berupaya untuk menghilangkan adegan mundur termasuk lebih bentuk permukiman tradisional. Makalah ini membahas bagaimana gambaran Singapura telah mempengaruhi bentuk Surabaya di kedua cara yang sistematis dan praktis, khususnya menangani sejauh mana obsesi ini dengan Singapura telah mempengaruhi Surabaya gambar dan identitas?
\end{abstract}

Kata kunci: Surabaya, image, identitas, Singapura, mimikri perkotaan 


\section{INTRODUCTION}

The phenomenon of transferring certain urban images across cities and countries is not a new trend. As King (1996) notes, a process of Manhattan Transfer has taken place in the Asia Pacific region. Indeed, in the case of Asia, Western cities such as New York, London, Los Angeles and Paris were looked to as models. For example, Marshall (2003) points out that Singapore's downtown was designed to mimic Los Angeles. However, in recent decades, urban studies have witnessed a shift away from Anglo-centric urban models to a phenomenon where inter-regional transfers between cities have been observed within Asia itself. Bunnell and Das (2010), for instance, identify that Kuala Lumpur in Malaysia is a 'model' for Hyderabad in India. In line with these developments, this paper seeks to reveal how Singapore became a model for city development in neighbouring Surabaya in Indonesia.

The appearance of modern urban development is a significant, influential factor amongst cities who aspire to 'world-class' status. Singapore has been extremely influential in inspiring other cities of the South East Asian region to transform their appearance to that of a 'world class city'. According to the American Journal Foreign Policy (2008), Singapore has obtained the seventh rank of the sixty top cities in the world. Thus, a dream to be another Singapore by mimicking Singapore's gleaming towers might become a strategy for South East Asian cities to match the aesthetic criteria associated with imagined global metropolises. This dream to be another Singapore certainly arises in Surabaya, Indonesia's second largest city. The Singaporean image is captured by and concentrated in the shining skyscrapers of Surabaya's Central Business District (CBD) area and by new residential areas with Singaporean themes, even as the traditional neighbourhood community known as kampung continues to dominate the rest of the city. The creation of Sing aporean replicas by private sectors in Surabaya is supported by the city municipality's actions through the Master Plan and the Vision Plan. The Surabaya Vision Plan (20052025), in particular, indicates the government's interest in adopting visual attractiveness of world-class cities including Singapore. Thus, the image of Singapore has been promoted in Surabaya through two approaches: systematic (via the planning system) and practical (via the private sector). A new form (or identity) of Surabaya, however, will not be simply defined as one identified as 'another Singapore' since Surabaya itself is complex in terms of cultures and characteristics, and thus a critical quest to formulate Surabaya's new identity to compete globally is needed. This paper will investigate a relatively new, prestigious residential development known as 'Citra Raya' that claims to bring Singapore to Surabaya in order to fulfil the dream of Surabaya's middle and upper class. It also examines Surabaya's Vision Plan (2005-2025) that highlights how waterfront development with Singapore as a model will be able to transform Surabaya into 'a trade service city'. 


\section{THEORY / RESEARCH METHODS}

\section{General Description of Surabaya}

Surabaya is located on the northern coast of East Java with population nearly three million. It is a municipality in the East Java Province covering nearly 30,000 hectares and is the second largest city in Indonesia. Surabaya's port serves as an entrance between East and West Indonesia and increasingly has become the main access point for Eastern Indonesia and international trading partners. Surabaya has maintained its position as a regional trading focus for over a century, and today continues to be the main port in East Indonesia. Surabaya's economy is driven by manufacturing, trade and business services (EDAW, 2005). After the 1997-1998 Asian economic crisis, economic growth in Surabaya stagnated at relatively low levels. More recently, however, it has since entered into a growth period with stable economic, social, and political conditions.

In the past 15 years, population in Surabaya has grown moderately (EDAW, 2005a). The natural growth of the base population increased by $0.5 \%$ from 2.5 million in 1990 to 2.6 million in 2000 (EDAW, 2005a). This base population is expected to grow at the current pace with stable population growth indicators such as life expectancy, fertility and mortality rates. In terms of immigrants, the number of registered net immigrants in each year is less than $0.1 \%$ of the total population according to EDAW. Population growth in Surabaya has however been primarily driven by the rising number of unregistered migrants (EDAW, 2005a). The Surabaya Vision Plan reported a conservative figure of 280,000 unregistered migrants in the year 2000. It also highlighted the high number of daily commuters to the city, which reach roughly 550,000 commuters on average per day. Despite the fact that the government anticipated this situation by improving regional infrastructure such as building the Suramadu Bridge to connect Surabaya and Madura, the number of commuters continues to increase due to high rates of immigration.

As the nation's second largest city, Surabaya's social development is more advanced than many cities in Indonesia. Basic education, health and water facilities are largely accessible to the general population. Furthermore, many key social indicators, including adult literacy rates and clean water access have improved within the last several years as a result of government investment and an expanding economy. Surabaya has a strong history of providing education, cultural and religious facilities. It is home to some of the nation's top universities and, as the "City of Heroes", occupies a significant place in Indonesian history.

Surabaya has been growing as a dualistic city. Even as it developed a formal process of urban development since late last century, Surabaya also developed through villages, which were gradually transformed into densely populated urban settlements known as kampungs. Silas (1996) highlights a significant role of kampungs in Surabaya's development. Kampungs make up only $7 \%$ of the total urban area but houses $63 \%$ of the people, mostly from the lower income groups (Silas, 1996). Further discussion of the role of kampungs will be explored in the following section. 
In terms of territory, Surabaya had significantly growth. The city's main road which used to define a ribbon of development, from 'Red Bridge' in the north to 'Wonokromo Bridge' in the South (approximately $13 \mathrm{~km}$ length), started to expand to the East and the West as a consequence of population growth and urbanization. Currently, Surabaya thus also shares similar development to other metropolitan cities: mass motorization, new industrial development and urban sprawl.

In the 1970s and early 1980s, Surabaya reached a peak of success under an enlightened mayor(Atkinson, 2001). In that period, Surabaya was recognized for its radical policy of acknowledging "the value contributed by the many hundreds of informal waste recyclers, providing them with an official status, encouraging them to organize into an association or union", which was known as "friends of the yellow crew" (Atkinson, 2001: 51). Participatory approaches were introduced to urban upgrading programs with assistance of a local university (Sepuluh November Institute of Technology - ITS). However, after a change of mayor, the support for participatory approaches to urban management declined. The subsequent Surabaya Mayor, Bambang Dwi Hartono, has held the position since 2002. His policy echoes that of Jakarta's government by focusing on urban beautification projects and linking the idea of improved planning of public spaces with the forceful removal of devastated conditions (Silver, 2008).

\section{RESULTS AND DISCUSSION}

\section{The Role of Kampung in Surabaya's Development}

As one of the oldest settlements in Indonesia, Surabaya has a long and interesting history (Silas, 1996). Historically, the Dutch colonizers had a big role in enhancing the development of the city, creating different landscapes of the Surabaya community by dividing it into four major areas, namely the European quarter, Chinese quarter, Arabian quarter and the Upper city. However, largely unaddressed were the informal kampung. The existence of this traditional form of settlement (kampung), spreading all over Surabaya, has played a significant role in the development of its more recent urban landscape. In terms of urban policy, unlike Jakarta, the capital city of Indonesia, which is more prone to take aggressive action by demolishing traditional parts of the city as a strategy to "improve" its urban aesthetics (and allegedly solve flooding problems), Surabaya seemed not to take such drastic action towards its traditional neighborhoods. The example of Surabaya's Kampung Banyu Urip which lay on a graveyard is instructive for, instead of evicting its squatters, the city government of Surabaya decided instead to evict "the dead" and support the efforts and investment of "these living people" who had already made real efforts to house themselves (Kerr, 2003).

Surabaya is a city that is proud of its culture and history. The public concern in developing Surabaya's real identity can be seen from an effort of Petra Christian University with its program known as "the Heritage Walk" that introduced two themes: "Journey to the Past" and "Tour de Kampoeng". One old kampung in North Surabaya that still exists today is known as Kampung Ampel. It surrounds a ceme- 
tery area where Sunan Ampel, the early Islamic leader in East Java, was buried. Located in the Arabic quarter, this funeral complex with its magnificent old mosque is a special tourist destination. The kampung surrounding the cemetery is highly valued and is certainly well taken care of. The case of Kampung Ampel also shows us that kampung not only house the low-income community but the middle income as well (Figure 1).

The spirit to promote Indonesia's real identity also includes a concern for its history. Some important parts of Surabaya represent its history, such as Monumen Bambu Runcing (Sharpened Bamboo monument) or Tugu Pahlawan (Heroic monument), which currently function as landmarks of Surabaya. Meanwhile, the obligation to preserve historic buildings linked to the Independence struggle is focused on the Hotel Majapahit (formerly Hotel Oranje). Although its historical role arises in the rhetoric of the Surabaya Vision Plan, it is only superficially discussed (Figure 2).

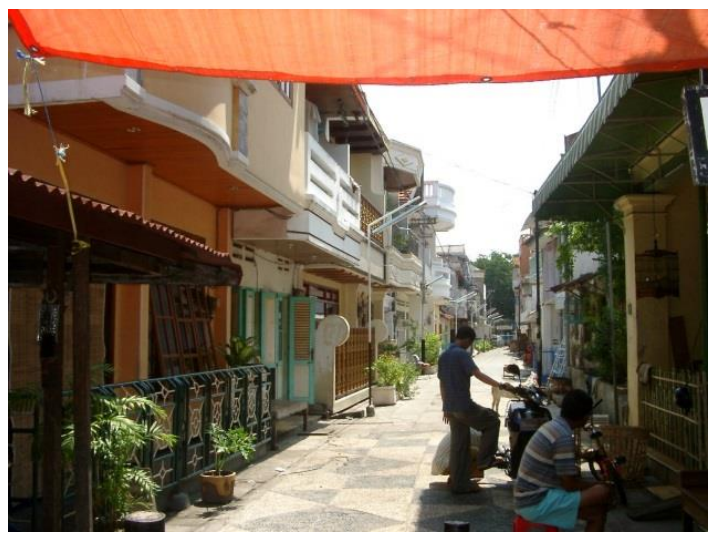

Figure 1. Kampung Ampel: A Tourist Destination Source: field survey, 2006

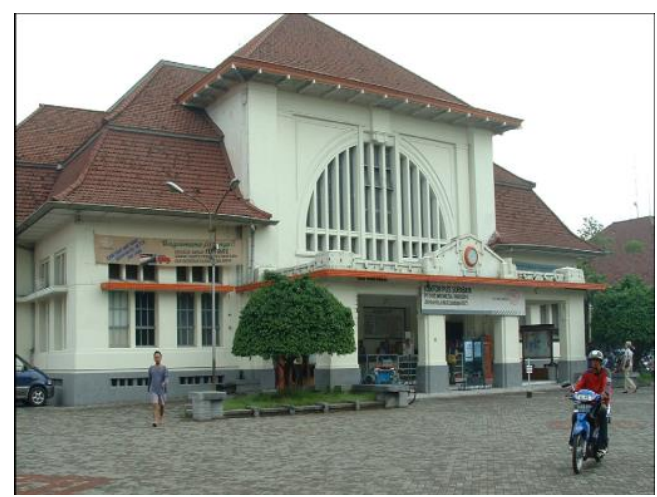

Figure 2. Surabaya is Colored with Unique Architecture, including this Post Office in the Downtown Area Source: Surabaya Vision Plan 2005-2025 
Surabaya has a strong city pattern with the coastal boundary in the northern part of the city and making a clear edge where the two main roads start. These roads connect the surroundings of Surabaya city to the Tanjung Perak harbour. One main road proceeds east-west from the southern boundary of the inner city, to connect Surabaya to an industrial estate, Tandes, in the north and to the northern towns of East Java. The other road runs southwards and connects the harbour to Surabaya center, with a sequence to follow: Tugu Pahlawan square (a landmark of Surabaya), hotel Majapahit area, Governor's office, Bambu Runcing (sharpened bamboo) monument then further south to the Surabaya industrial estate Rungkut. It ends at Juanda airport.

\section{Surabaya: Towards An Ambitious Dream}

The framework of planning in Surabaya in the reform (post-Soeharto) era has echoed both Jakarta's planning as well as more global planning rhetoric, embracing terms such as sustainability, inclusiveness, equity and environmentalism (Silver, 2008). Despite this shift of the planning rhetoric towards promoting citizen inclusiveness, the roles and ideas of planners and architects (particularly those who work for the government) continue to dominate discussions regarding Surabaya's future.

"The future of the cities of the world can be in our hands. But we need a dream. For, as Martin Luther said, if you don't have a dream, you can't have a dream come true. (Sgoutas, 2002: 346)"'

The above quotation from Vassilis Sgoutas argues that there is a need for engagement and enthusiasm in improving the condition of cities. Sgoutas (2002) also notes that architects have the role to lead to better cities and to more equitable built environments. The call for a vision to inspire development is supported by Friedmann 'in defense of utopian thinking' (Friedmann, 2002: 103).

Seeking to transform Surabaya into 'another Singapore', the city government in the Surabaya Vision Plan (2005-2025) highlights its role as a service city, promoting its expansion as a trade service centre (EDAW, 2005: 33). In conjunction with the Surabaya planning scheme, private groups have promoted a theme of ' $\mathrm{Su}$ rabaya, a shopping city' to boost tourism and investment. This message has been expressed in newspapers and internet to market Surabaya as a tourism destination. Thirteen shopping centers have been built across the city over a decade in accordance with this vision. Government planners claimed that the decision to permit shopping centre developments accommodated both public and private interests. The image of shopping malls as an ideal, comfortable, secure and sanitized community space (Dovey, 1999) was promoted, implying advantages for the broader Surabaya community. Indeed, shopping malls are routinely visited by all socio-economic groups of people for various purposes (such as window shopping, meeting, etc). However, for some of Surabaya's residents, particularly the aged population, lowrise buildings and smaller shopping stores (such as traditional markets or mini markets) appear to be more favoured since they allow two-way interactions (dialogue) and are easier to navigate than larger shopping malls. Criticism of the approval of 
the mass development of shopping centers and trade centers has been expressed by some members of the city's House of Representative (Irawulan, 2007). Not only has retail mall development in Surabaya failed to integrate with the city's existing economic capacity, many of these shopping malls have also been unsuccessful, characterized by decreasing numbers of customers as a result of competition and increasing numbers of vacant stores.

Surabaya's Vision Plan (2005-2025) expresses another set of ambitious development goals, with the redevelopment of the Kali (river) Mas identified as a top priority (Figure 3 ). It is claimed that enhancing the waterfront and coastal development will lead to the transformation of Surabaya from an 'industrial city' into a 'trade service city' (EDAW, 2005: 33). This vision has been influenced by the examples of six different cities, perceived by Surabaya authorities as having achieved world city status: Singapore, Metro Manila, Hong Kong, Shenzhen, San Diego and Melbourne, partly due to their waterfront redevelopment initiatives (EDAW, 2005: 33). Surabaya authorities have attempted to show their commitment to the waterfront city concept to potential investors by undertaking a series of evictions of kampungs which had densely occupied the riverside.In early 2002, the Surabaya municipality, supported by East Java province, released the project for revitalization of the Wonokromo riverbank. The first stage of the project demolished nearly 1,150 (illegal) houses erected across a five kilometer length of riverbank (Jasa Tirta, 2002). 700 people who were evicted have finally been resettled by the municipality to lowincome, rental, walk-up flats after nearly two and a half years of homelessness. The case of Surabaya planning shows the power of (global) image in development. The city planners simply viewed kampung as undesirable and encouraged their demolition through various planning mechanisms as part of their wider urban redevelopment project.

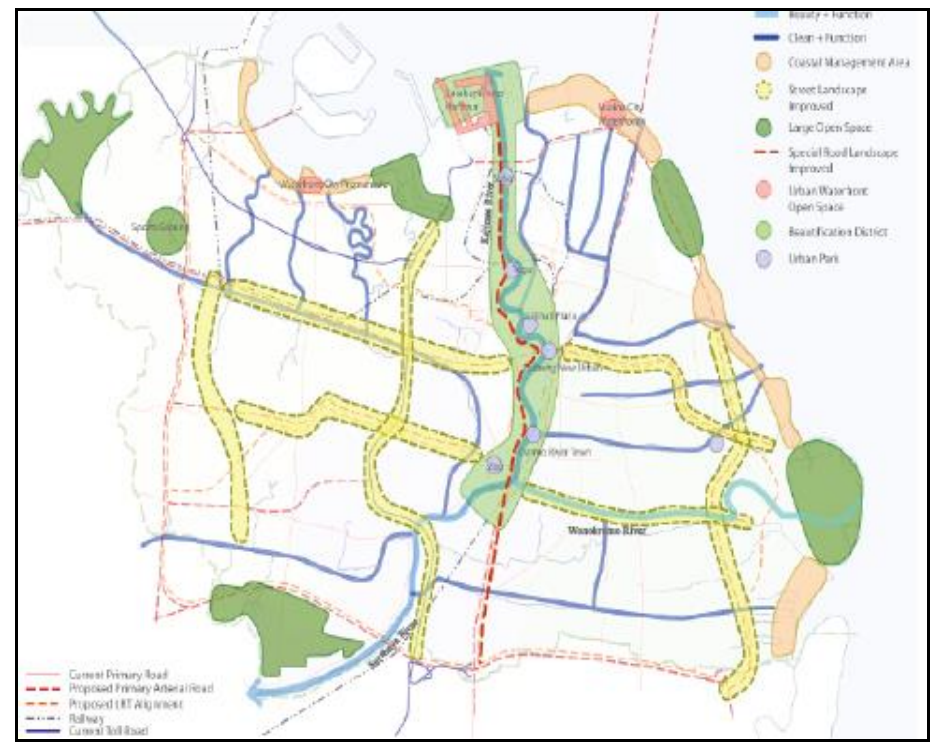

Figure 3. River Redevelopment Plans

Source: Surabaya Vision Plan 2005-2025 


\section{Citra Raya: the Singapore of Surabaya}

Citra Raya is the largest real estate project in Indonesia located 15 kilometers to the west of Surabaya. By 2006, the estate had developed 700-800 hectares of its total projected area of 2,000 hectares and had built more than 9,200 houses. Its target market is the middle and upper income groups, especially expatriates living or working in Surabaya. Citra Raya boasts impressive features including extensive landscaping, wide roads, high quality housing facilities, and an international scale golf course. Indeed, Citra Raya does not seem to be in Surabaya at all.

Developing from the concept of a satellite town, this estate, accompanied by other estates nearby, has created a different residential sphere in Surabaya. Harsh competition between real estate developers has pushed Citra Raya to become innovative in its design and marketing. The current marketing strategy of Citra Raya focuses on executives and expatriates in Indonesia, to present an idea of a modern Singaporean housing style - clean, green and modern. Citra Raya claims that they seek to realize local residential living aspirations (PT. Ciputra Annual, 2005). Furthermore, they assert that Singapore is particularly appealing to residents of Surabaya and a 'dream world' for Indonesian people of the middle and upper classes. This is also supported by a study of Citra Raya Housing Estates which shows the most important factor considered by customers in buying property in Citra Raya is the implementation of bringing Singapore to Surabaya (Anastasia et.al., 2005).

In line with the literature that underlines the importance of symbols or icons in relation to sense of place, Citra Raya has also adopted specific icons associated with Singapore and has merged them into the residential landscape. Singaporean icons such as the Merlion (Figure 4), Fountain of Wealth, Raffles' Statue, and the Obelisk have been copied, albeit in different sizes to create a 'miniature' Singapore in Surabaya. In addition to these icons as symbols of Singapore, Citra Raya management also adopts the concept of a modern, green and clean city, which has been actively promoted by the Singaporean government. However, the claims in relation to Citra Raya are based on marketing rather than any genuinely sustainable features.

The desire to adopt an image from other cities must be accompanied with sensitivity to local values or a sufficient knowledge of what the adopted symbols mean for their culture or nation of origin. The case of adopting the Raffles' statue (from Singapore to Citra Raya) illustrates this inappropriateness as it is a symbol of the colonial era opposed by nationalistic Indonesia. The replica inspired criticism from the Heritage Preservation Association as expressed by an article written on the official website of the Department of Information and Communication (2004): "the Raffles' statue, five meters high, is badly chosen to be erected on the Citra Raya estate, since Raffles is a representative of colonialism who brought misery to Indonesia". This resulted in the Citra Raya management removing the original head of the Raffles' statue and replacing it with a bust of Beethoven (Figure 5). 


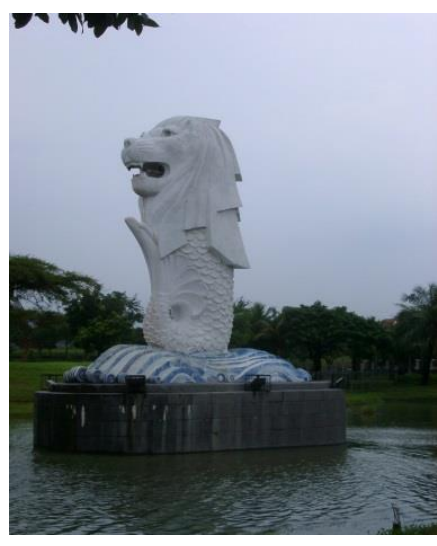

Figure 4. The Merlion in Citra Raya Source: field survey, 2006

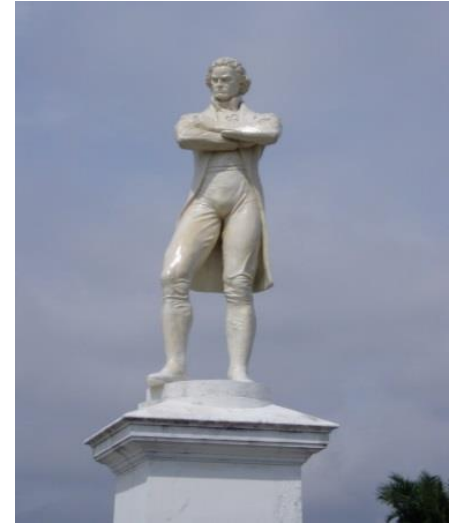

Figure 5. Bethoven Statue in Citra Raya Source: field survey, 2006

Moving to its commercial built environment, the simulation of world city landmarks extends to the construction of the retail precinct, with each main store representing a famous monument, such as London's Big Ben. These duplications and replications have brought about something akin to what Anderson (1991) has suggested as an imagined community going beyond the culture of a particular nation (Figure 6). The myth that global images can represent a global community, however, remains speculative. These attempts to adopt well-known 'ideal images' (Laseau 2000) tend to simplify the design process and to dismiss any requirement of critical thought regarding images.

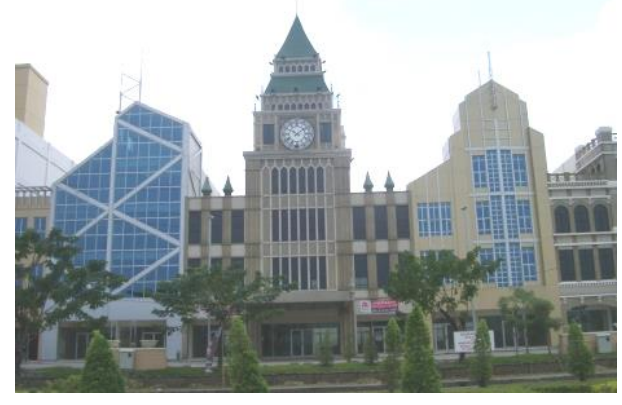

Figure 6. Retail Precinct Duplicating International Landmarks Source: field survey, 2006

\section{Singapore and Surabaya Connections}

To understand the recent phenomenon observable in Surabaya, the comparative method of studying cities as suggested by McFarlane (2010) is useful. As McFarlane (2010: 15) argues, "comparative thinking informs research and imaginative geographies... [and] is useful for a more postcolonial urbanism". In addition, Ward (2010: 
483) argues for a comparative approach which recognizes "the territorial and relational geographies of cities". Despite the fact that both scholars suggest some techniques in comparing cities such as revealing differences and similarities, this paper aims more to reveal the relational connection between Singapore and Surabaya.

The previous section has underlined a systematic way to observe how an idea to be another Singapore or another world class city has penetrated into Surabaya's planning system. Although the city's authorities have studied six cities, Singapore has become the most influential city for Surabaya's development. There are some factors to explain the importance of Singapore to Indonesia in general and to Surabaya in particular.

Geographically, Singapore is the closest to Surabaya in distance compared to the other five cities studied and thus provides more opportunities for Surabaya's residents to visit Singapore compared to the other cities. Accessibility and affordability has improved with an increase in direct flights and cheaper flight prices to Singapore. In addition, Singapore and Indonesia also share similar histories as postcolonial countries, and thus a sense of familiarity between these two countries is intense. Moreover, Singapore is also a place for rich Indonesians to invest. According to Merrill Lynch and Capgemini (2007),

"...one-third of high net-worth investors in Singapore were of Indonesian origin [in 2006]. It estimated that some 18,000 wealthy Indonesians had assets of $\$ 87$ billion invested there, although only a handful would be of interest to Indonesian law enforcement officials. (New York Times, 2007)"

However, there is growing evidence that because of Singapore's banking secrecy law, this city "has become a safe heaven for criminals particularly economic criminals from Indonesia" (New York Times, 2007). However, for most Indonesians, this situation has not reduced their respect for or interest in Singapore.

Whilst Surabaya has a tendency to adopt the image of Singapore for some reasons and purposes, it is necessary to explore Singapore's dynamic development strategy to reach world-city status. In the 1970s, the development of Singapore focused on urban renewal that produced "garden attractions and modern hotels" (Chang and Yeoh, 1999: 104). In the 1980s, the concern for urban heritage became significant and introduced a policy to "infuse a sense of historicity in an increasingly modern landscape" (Chang and Yeoh, 1999: 104). In the 1980s, the governmentcommissioned Tourism Task Force recommended the "conservation of cultural areas and historical sites" (Chang and Yeoh, 1999: 105) and therefore produced a redevelopment plan of ethnic enclaves and historic areas. In 1990s a new Master Plan was released covering the Strategic Plan for Growth which highlights the need to enhance Singapore's urban landscape. Entering the new millennium, Singapore proposed a strategy to market Singapore by promoting the "New Asia - Singapore", to imply the coexistence of "Western and Asian cultures" (Chang and Yeoh, 1999: 105). The idea is promoting a two-way relationship between culture and tourism: “while tourism provides an opportunity for Singapore's cultural resources to be redefined, likewise cultural landscapes are refashioned to meet the challenges of tour- 
ism in the new millennium" (Chang and Yeoh, 1999: 105). More recently Singapore in the Economic Development Board's official website promotes Singapore as "a dynamic global city" (EDB, 2009).

Singapore might be judged successful in its journey to seek for its identity, although there is a need to constantly redefine or refashion to maintain its dynamic attraction. In contrast, Surabaya is in an ongoing process in searching for an appealing identity in the shadow of Singapore.

\section{CONCLUSIONS}

Modeling development strategies on those of advanced cities is not a new phenomenon. As previously stated, Singapore's downtown was also designed to copy the image of other nations (Marshall, 2003). However, such strategies are questionable given that the urban images of other cities reflect the socio-economic conditions of a particular culture and period of time. Citra Raya provides a powerful example of a development that is modelled after Singapore in accordance with the government policy to attract international investment as reflected in the new retail malls and large-scale residential property development. There might be an inclination to dismiss Citra Raya as a poor copy. However, to some extent, it does conform to one community's idea of identity. This paper could well have referred to other sectors of the city, to their images, and to those communities who value those identities.

By contrast, the kampung that symbolizes Indonesia's traditional settlement form is currently out of favour with the city government for its apparent disorder and disassociation from major processes of investment and development. The city authorities seem oblivious to the potential of kampung to promote and sustain the indigenous socio-cultural values that are embedded in the everyday life of inhabitants. In many cases, the threat of eviction faced by the kampung is exacerbated by its illegal land status (occupying government land) although, for most, the main reason is that it represents an obstacle to the city's waterfront redevelopment ('beautification') plans.

Although this paper implies a criticism of the fawning attitude towards Singapore in the development of Citra Raya and of a lack of imagination on the part of its designers, the real criticism here is of the Surabaya Vision Plan and its public sector implementation. Only selected identities are chosen to be enhanced - the 'Green Corridor', a few areas of older (mainly colonial) architecture, and green waterfronts. The other identities, which happen to be those of the majority of Surabayans, are ignored at best and demolished at worst. It is inevitable for Surabaya to draw upon the flow of modern images offered by global forces. In fact, for some Indonesian communities, these 'sparkling' images to some extent confirm their sense of identity. However, such strategies are questionable given that the homogenisation of the urban images of others will eventually diminish the attractiveness of Surabaya. It raises the question of why tourists would bother to come to Surabaya when they can find the experience in Singapore or elsewhere. It is therefore important to understand that cities compete by being different rather than being the same. 
The richness of Surabaya, as of any other city, is dependent upon its diversity. The loss of those traditional communities would reduce that richness. As Surabaya seeks to become a world-class city, there is a critical call for the formation of a unique identity. Indeed, even as it is necessary for cities to apply a modern look (as represented by Singapore), it is also crucial to present uniqueness. A modern (worldclass) city will typically exhibit malls, tall buildings, and similarly glamorous urban forms, while also presenting more traditional urban forms such as those represented in kampung. These multiple identities remind us that Surabaya has had multiple communities from its earliest establishment. Thus, displaying those multi identities offers attractiveness in marketing Surabaya as a tourism destination as well as an appealing locale for global investment. Finally, there is a critical task for Surabaya's municipality to decide their identity: to be another Singapore or to redefine their own identity.

\section{REFERENCES}

American Journal Foreign Policy (2008), The 2008 Global Cities Index, <http://www.foreignpolicy.com/story/cms.php?story_id=4509> (Accessed on 31 May 2010).

Anastasia, N., et al. (2005), Analisa Faktor-faktor yang Dipertimbangkan Konsumen Dalam Pembelian Property di Citraraya Surabaya, Civil Engineering Dimension, 7(2), 75-80, The Institute of Research \& Community Outreach - Petra Christian University, Surabaya.

Anderson, B. (1991), Imagined Communities: Reflections on the Origins and Spread of Nationalism, Verso, London.

Atkinson, A. (2001), Surabaya, Indonesia: Local Agenda 21 in the Context of Radical Political Reform, City, 5(1), 47-65, Taylor \& Francis.

Bunnell, T. and Das, D. (2010), Urban Pulse - A Geography of Serial Seduction: Urban Policy Transfer from Kuala Lumpur to Hyderabad, Urban Geography, 31(3), 277-284, John Wiley \& Son.

Dick, H. W. (2003), Surabaya City of Work: a Sosioeconomic History, 1900-2000, Singapore University Press, Singapore,

Dovey, K. (1999), Framing Places: Mediating Power in Built Form. London, New York, Routledge.

EDAW (2005), Surabaya Vision Plan 2005-2025, Surabaya Board Planning, Surabaya.

EDAW (2005a), Surabaya Vision Plan 2005-2025 (Workshop report), Surabaya Board Planning.

Ford, L. R. (1993), A Model of Indonesia City Structure, Geographical Review, 83(4), 374-396, Wiley, New York.

Friedmann, J. (2002), The Prospect of Cities, University of Minnesota Press, Minneapolis, London.

Idawati, D. E. (2009), Distorted Communication: the Struggle of Squatter Settlements along the Surabaya Riverbank, Unpublished Dissertation, University of Melbourne, Melbourne. 
Irawulan (2007), DPRD Jatim Ingatkan Pemkot Surabaya Stop Bangun Mal, <http://surabaya.detik.com/read/2007/09/11/172326/828580 /466/dprd-jatimingatkan-pemkot-surabaya-stop-bangun-mal> (Accessed on 11 September 2007).

Jasa Tirta (2002), Penataan Kembali Bantaran Sungai kali Wonokromo, <http://members.bumn-ri.com/jasa_tirta1/news.html> (Accessed on 7 September 2005).

Kerr, T. (2003), Causes of Eviction, Housing by People in Asia, 15, Newsletter of the Asian Coalition for Housing Rights.

King, A. D. (1996), Worlds in the City: Manhattan Transfer and the Ascendance of Spectacular Space, Planning Perspective, 24, 95-114.

Laseau, P. (2000), Architectural Representation Handbook, McGraw-Hill.

McFarlane, C. (2010), The Comparative City: Knowledge, Learning, Urbanism,International Journal of Urban and Regional Research, 34(4), 725-742, Blackwell Publishing Ltd.

New York Times (2007), Indonesia and Singapore Sign Two Landmark Treaties, <http://www.nytimes.com/2007/04/27/world/asia/27iht-indo.3.5474698.html?_r=1> (Accessed on 15 June 2010).

Silas, J. (1996), Kampung Surabaya Menuju Metropolitan, Yayasan Keluarga Bhakti Surabaya, Surabaya.

Silver, C. (2008), Planning the Megacity: Jakarta in the Twentieth Century, Routledge, London.

Ward, K. (2010), Towards a Relational Comparative Approach to the Study of Cities, Progress in Human Geography, 34(4), 471-487. 
Idawati: A CASE OF URBAN MIMICRY: CITRA RAYA, THE SINGAPORE OF SURABAYA

This page intentionally left blank 